\title{
Perbandingan Efektivitas Berbagai Media Ovitrap terhadap Jumlah Telur Aedes Spp yang Terperangkap di Kelurahan Jati Kota Padang
}

\author{
Gusti Rati ${ }^{1}$, Hasmiwati ${ }^{2}$, Erlina Rustam ${ }^{3}$
}

\begin{abstract}
Abstrak
Aedes spp adalah vektor pembawa virus dengue yang dapat menimbulkan penyakit Demam Berdarah Dengue (DBD). DBD merupakan penyakit menular yang cenderung mengalami peningkatan dan penyebarannya semakin luas. Cara mengurangi penyebaran penyakit DBD dengan mengendalikan vektor, salah satunya dengan memutus siklus hidup vektor dengan menggunakan perangkap telur/pemasangan ovitrap. Tujuan penelitian ini adalah untuk membandingkan efektivitas berbagai media ovitrap terhadap jumlah telur Aedes spp yang terperangkap. Jenis penelitian ini adalah eksperimental quasi dengan rancangan post test only design. Populasi dalam penelitian ini adalah semua telur Aedes spp yang terperangkap pada ovitrap, sampel diambil dari sepuluh rumah dengan ulangan enam kali. Lokasi penelitian adalah RW I, III, V, VII, IX Kelurahan Jati. Variabel bebas adalah berbagai media (air sumur, air jerami, air kolam, air mineral) ovitrap. Variabel terikat adalah jumlah telur Aedes spp yang terperangkap. Uji normalitas data menggunakan uji kolmogorov smirnov, data terdistribusi normal $(p>0,05)$ dan uji varian data tidak homogen $(p<0,05)$, maka dgunakan uji Kruskal Walls dan Mann Withney. Hasil penelitian diperoleh telur nyamuk Aedes spp yang terperangkap selama penelitian adalah 3.090 butir dengan sebaran 1.563 butir di luar rumah dan 1.527 butir di dalam rumah. Berdasarkan media ovitrap, telur yg terperangkap pada media air jerami 1.758 butir, air mineral 576 butir, air kolam 523 butir, air sumur 233 butir. Uji statistik mendapatkan $p=0,000$. Hal ini menunjukkan bahwa terdapat perbedaan jumlah telur Aedes spp yang terdapat pada masing-masing media ovitrap. Disimpulkan bahwa air jerami lebih efektif sebagai media ovitrap daripada air mineral air kolam, air sumur.
\end{abstract}

Kata kunci: telur Aedes spp, ovitrap, media ovitrap

\section{Abstract}

Aedes spp are vectors of dengue viruses that can cause Dengue Hemorrhagic Fever (DHF). Dengue is one of the infectious diseases that the number of sufferers tend to increase and has wider dissemination. The solution to decrease the spread of dengue is by control the vector by using Ovitrap. The objective of this study was to compare the effectiveness of various media ovitrap on the number of Aedes spp eggs trapped. This research was a quasi experimental with post test only design. Population were all Aedes spp eggs trapped in ovitrap, samples were taken from 10 homes with 6 times repeatation. Location of the study were RW I,III, V, VIII,IX in Jati . The independent variable is the type of media (wells water, straw water, pool water, mineral water) ovitrap. The dependent variable is the number of Aedes spp eggs trapped. The result of Kolmogorov Smirnov test were normally distributed $(p>0.05)$, a variant of the test data is not homogeneous ( $p<0.05)$, so analyzed using the Mann Whitney and Kruskal Walls. The Aedes spp mosquitoes that trapped during the study were 3,090 eggs. The distribution of 1,563 eggs outside the home and 1,527 eggs in the house. According to media ovitra; straw water had 1758 eggs, mineral water had 576 eggs, pools water had 523 eggs, well water had 233 eggs $(p=0.000)$. There is a diference from the four ovitrap media on the eggs Aedes spp. The conclution is the straw water media is more effective than water of mineral, pools and well.

Keywords: eggs of Aedes spp, ovitrap , ovitrap media 
Affiliasi penulis: 1 Pendidikan Dokter FK UNAND (Fakultas Kedokteran Universitas Andalas Padang), 2. Bagian Parasitologi FK UNAND, 3. Bagian Farmakologi FK UNAND.

Korespondensi: Gusti Rati. Email: gustirati09@gmail.com, Telp: 085363356902

\section{PENDAHULUAN}

Aedes aegypti merupakan vektor pembawa virus dengue yang dapat menimbulkan penyakit Demam Berdarah Dengue (DBD). Aedes aegypti juga merupakan pembawa virus demam kuning (yellow fewer) dan cikungunya. Spesies lain dari Aedes spp seperti Aedes albopictus juga dapat berperan sebagai vektor namun Aedes aegypti tetap menjadi vektor utama dalam penyebaran DBD. ${ }^{1}$

DBD merupakan penyakit menular yang menjadi masalah kesehatan di dunia yang jumlah penderitanya cenderung mengalami peningkatan dan penyebarannya semakin luas. ${ }^{2}$ DBD dapat menyerang semua orang dan dapat menimbulkan kematian terutama pada anak, serta sering menimbulkan Kejadian Luar Biasa (KLB). ${ }^{3}$

Sumatera Barat merupakan salah satu propinsi yang mengalami peningkatan jumlah kasus DBD. Tahun 2010 jumlah DBD adalah 1.795 kasus, meningkat tahun 2011 sebanyak 2.199 kasus dan data terakhir tahun 2012 kasus DBD meningkat lagi menjadi 3.158 kasus. DBD yang paling tinggi terdapat di Kota Padang sebanyak 1.626 kasus tahun 2012. Periode Januari hingga Desember 2012 tercatat 10 orang meninggal dunia akibat DBD. ${ }^{4}$

Data Dinas Kesehatan Kota Padang lingkungan Puskesmas Andalas merupakan daerah yang paling banyak kasus DBD. Data dari Puskesmas Andalas Kota Padang, menyatakan kelurahan Jati merupakan daerah yang mengalami KLB dari 10 kelurahan di wilayah Puskesmas Andalas. Kasus DBD di Jati Tahun 2001 dan 2002 terdapat 6 kasus, tahun 2003 terdapat 10 kasus, tahun 2004 terdapat 7 kasus, tahun 2005 terdapat 20 kasus dan tahun 2011 kasus DBD meningkat menjadi 23 kasus. $^{5}$

Berdasarkan hal tersebut, perlu diberikan suatu pemantauan keberadaan Aedes spp yang memanfaatkan genangan air sebagai tempat perindukannya, salah satunya dengan cara pemasangan ovitrap sehingga dapat mendeteksi apakah di dalam dan sekitar rumah menjadi tempat perkembangbiakan nyamuk vektor DBD tersebut atau tidak. $^{6}$

Ovitrap pertama kali dikembangkan oleh Fay dan Eliason pada tahun 1996, kemudian digunakan oleh Central for Diseases Control and Prevention (CDC) dalam surveilan Ae. aegypti. Alat ini telah berhasil diterapkan di Singapura dengan memasang 2.000 ovitrap. $^{8}$ Ovitrap (perangkap telur) adalah suatu alat sederhana berupa bejana (kaleng plastik) yang dindingnya dicat hitam dan diberi air secukupnya untuk menarik Aedes spp bertelur. Ovitrap mudah dilakukan dan dapat diterapkan dimana saja dan tidak menimbulkan dampak negatif pada lingkungan seperti halnya pengasapan. ${ }^{7}$

Keberadaan air pada ovitrap juga mempengaruhi tempat perindukan nyamuk Aedes spp. Jentik sering ditemukan pada tempat penampungan air yang tergenang. Berdasarkan hal tersebut maka perlu diteliti tentang perbandingan efektivitas berbagai media ovitrap terhadap jumlah telur Aedes spp di kelurahan Jati.

\section{METODE}

Jenis penelitian adalah eksperimental quasi dengan rancangan post test only design. Populasi adalah semua telur Aedes spp yang terperangkap pada ovitrap dengan menggunakan beberapa media seperti: air kolam, air sumur, air jerami, air mineral. Tempat pemasangan ovitrap dilakukan pada 10 rumah yang berada di RW I,III,V,VII,IX kelurahan Jati, dengan enam kali ulangan. Pemilihan tempat pemasangann sampel dilakukan dengan sistem random sampling.

Data yang diperoleh adalah data yang didapat langsung di Kelurahan Jati yaitu berupa jumlah telur nyamuk Aedes spp yang terperangkap pada ovitrap pada masing-masing media. Data yang didapat kemudian dianalisis dengan analisis univariat yang disajikan dalam bentuk tabel untuk melihat perbedaaan jumlah telur Aedes spp yang terperangkap di kelurahan Jati. Analisis multivariat dengan uji statistik Kruskal Walls dan Mann Whitney yang disajikan dalam bentuk tabel 
HASIL

Penelitian yang dilakukan terhadap jumlah telur Aedes spp, dengan enam kali pengulangan yang didapatkan hasilnya seperti tertera pada tabel yang di letakkan pada sepuluh rumah (RW I, III, V, VII, IX) terdapat dibawah ini..

Tabel 1. Jumlah ovitrap positif yang berisi telur di Kelurahan Jati kota Padang

\begin{tabular}{ccccccccc}
\hline \multirow{2}{*}{ Ulangan } & \multicolumn{2}{c}{ Air kolam } & \multicolumn{2}{c}{ Air sumur } & \multicolumn{2}{c}{ Air Mineral } & \multicolumn{2}{c}{ Air Jerami } \\
\cline { 2 - 9 } & L & D & L & D & L & D & L & D \\
\hline 1 & 6 & 5 & 5 & 1 & 7 & 6 & 6 & 7 \\
2 & 4 & 4 & 3 & 1 & 4 & 4 & 6 & 7 \\
3 & 4 & 6 & 5 & 3 & 3 & 7 & 5 & 6 \\
4 & 2 & 5 & 4 & 2 & 5 & 8 & 4 & 7 \\
5 & 3 & 5 & 6 & 5 & 4 & 1 & 6 & 9 \\
6 & 5 & 6 & 3 & 3 & 2 & 3 & 3 & 7 \\
\hline jumlah & 24 & 31 & 26 & 15 & 25 & 29 & 30 & 44 \\
\hline D= dalam & L= luar & & & &
\end{tabular}

Tabel 2. Jumlah temuan telur pada ovitrap di kelurahan Jati kota Padang

\begin{tabular}{cccccccccc}
\hline Ulangan & \multicolumn{2}{c}{ Air kolam } & \multicolumn{2}{c}{ Air Sumur } & \multicolumn{2}{c}{ Air Mineral } & \multicolumn{2}{c}{ Air Jerami } \\
\cline { 2 - 10 } & L & D & L & D & L & D & L & D \\
\hline 1 & 37 & 41 & 21 & 5 & 53 & 50 & 153 & 188 \\
2 & 21 & 33 & 10 & 27 & 60 & 42 & 176 & 201 \\
3 & 38 & 38 & 25 & 9 & 41 & 39 & 67 & 53 & 94 \\
4 & 94 & 47 & 25 & 13 & 69 & 48 & 133 & 164 & 193 \\
5 & 58 & 44 & 29 & 37 & 53 & 51 & 13 & 136 & 200 \\
6 & 21 & 51 & 22 & 10 & 57 & 333 & 243 & 829 & 930 \\
\hline jumlah & 269 & 254 & 132 & 101 & & 576 & & & 1.759 \\
\hline
\end{tabular}

Tabel 3. Rekapitulasi hasil uji statistik variabel penelitian di Kelurahan Jati kota Padang

\begin{tabular}{|c|c|c|c|c|}
\hline Jenis ovitrap & $p-\mathrm{KW}^{*}$ & Perbedaan jenis ovitrap & $p-\mathrm{MW}^{\star \star}$ & Keterangan \\
\hline Mineral & 0,000 & Mineral-Sumur & 0,004 & Ada perbedaan \\
\hline Sumur & & Mineral-Kolam & 0,004 & Ada perbedaan \\
\hline Kolam & & Mineral- Jerami & 0,092 & Tidak ada perbedaan \\
\hline \multirow[t]{3}{*}{ Jerami } & & Sumur- Kolam & 0,006 & Ada perbedaan \\
\hline & & Kolam- Jerami & 0,004 & Ada perbedaan \\
\hline & & Sumur-Jerami & 0,004 & Ada perbedaan \\
\hline
\end{tabular}

* $\quad \mathrm{KW}=$ Kruskal Walls $\quad$ ** $\quad \mathrm{MW}=$ Mann Whitney

\section{PEMBAHASAN}

Hasil penelitian yang dilakukan di Kelurahan Jati pada bulan April 2014 diperoleh jumlah ovitrap yang positif berisi telur Aedes spp dan jumlah telur Aedes spp yang menepati masing - masing media ovitrap (Tabel 1dan 2), terdapat variasi jumlah telur Aedes spp yang terdapat pada media ovitrap. Jumlah telur Aedes spp yang terperangkap selama enam kali pengamatan adalah 3.090 butir. Jumlah perolehan telur pada ovitrap paling tinggi terdapat pada air jerami 1.758 butir dengan indeks ovitrap 61,7\%, air mineral 576 butir dengan indeks ovitrap 45\%, air kolam 523 butir dengan indeks ovitrap 45,8\%, dan air sumur 233 butir dengan indeks ovitrap 34,1\%.

Perolehan jumlah telur Aedes spp lebih banyak ditemukan pada air rendaman jerami. Hal ini berarti air rendaman jerami lebih disukai daripada air 
kolam, sumur dan mineral. Pada air rendaman jerami terjadi proses fermentasi secara anaerob. Hasil fermentasi rendaman jerami biasanya berwarna kuning keruh dan beraroma menyengat. Bau menyengat dari air rendaman jerami adalah hasil fermentasi berupa $\mathrm{CO}_{2}$ dan amoniak. Senyawa ini tebukti dapat mempengaruhi saraf penciuman dan mempengaruhi nyamuk Aedes spp dalam memilih container sebagai tempat bertelur. ${ }^{8}$

Hasil penelitian ini sejalan dengan yang telah dilakukan oleh Lelono tahun 2010 yang mendapatkan bahwa air jerami lebih banyak dijumpai telur Aedes spp daripada media yang lainnya. Pada penelitian ini ovitrap yang berisi rendaman jerami memperlihatkan indeks ovitrap $61,7 \%$ dengan jumlah telur 1.758 butir, sedangkan penelitian Lelono tahun 2010 mendapatkan jumlah telur sebanyak 420 butir. Jumlah tersebut merupakan perolehan telur paling banyak daripada media lain (air aquades, air kelapa, air hujan, air kolam, air sumur, air mineral) yang digunakan oleh Lelono dalam penelitiannya. ${ }^{10}$

Jumlah ovitrap yang positif telur Aedes spp dapat dilihat berdasarkan kondisi perumahan di Kelurahan Jati yang cenderung padat dan jarak antar rumah yang berdekatan. Luas wilayah $0,61 \mathrm{~km}^{2}$ dengan Jumlah penduduk mencapai 10.497 jiwa. $^{9}$ Rata-rata ovitrap yang positif lebih banyak di temukan pada rumah yang kebersihannya kurang terjaga seperti terdapatnya pakaian yang bergelantungan di kamar mandi dan tumpukan pakaian dalam ember. Ovitrap yang diletakkan pada tempat yang gelap dengan pencahayaan yang redup menghasilkan telur lebih banyak. Hal itu terjadi karena kebiasaan nyamuk Aedes spp jika sudah menghisap darah, nyamuk akan beristirahat di tempat yang gelap sampai proses penyerapan darah untuk permatangan telur selesai. Setelah itu Aedes spp akan mencari tempat yang berair dan bertelur ditempat yang gelap dan tersembunyi. Kondisi ini sesuai dengan yang disampaikan Firdaus tahun 2003 yang menyatakan bahwa nyamuk Aedes spp suka beristirahat dan bertelur di tempat yang gelap, lembab, dan tersembunyi di dalam rumah. ${ }^{1}$

Berdasarkan Tabel 2 dapat diketahui bahwa jumlah telur kedua terbanyak terdapat pada air mineral. Pada perolehan jumlah telur Aedes spp, air mineral mempunyai jumlah telur yang lebih banyak daripada air kolam. Jumlah telur yang terdapat pada air mineral adalah 576 butir, sedangkan jumlah telur yang terdapat pada air kolam adalah 523 butir. Keadaan ini mengindikasikan bahwa nyamuk Aedes spp suka bertelur pada media air mineral. Seperti yang diketahui bahwa telur nyamuk menetas dan berubah menjadi larva yangmem erlukan media untuk dapat tumbuh dan berkembang menuju tahap selanjutnya yaitu pupa. Kandungan air mineral dapat dimanfaatkan oleh larva sebagai media untuk tumbuh. ${ }^{10}$

Berdasarkan Tabel 2 diketahui bahwa air sumur kurang diminati karena perolehan telur Aedes spp ditemukan paling sedikit jika dibandingkan dengan media yang lain. Jumlah perolehan telur pada air sumur sebanyak 233 butir telur. Air sumur merupakan sarana air bersih yang mengambil air dari lapisan tanah dengan cara menggali lubang dari tanah dengan kedalaman tertentu mulai dari 3-15 meter tergantung pada tofografi tanah setempat. Biasanya air sumur relatif dekat dengan tanah permukaan, sehingga dapat terkontaminasi melalui rembesan. Kontaminasi paling umum karena penapisan air dari sarana pembuangan kotoran manusia dan binatang yang dapat mempengaruhi kelangsungan hidup larva. Kelangsungan hidup larva juga tergantung pada keberadaan plankton.Plankton yang terdapat pada air sumur sangat sedikit jika dibandingkan dengan air yang lain sehingga larva tidak dapat bertahan hidup dalam waktu yang lama karena kekurangan asupan makanan. Menurut Pandujati yang melakukan penelitian pada tahun 2009 menyatakan bahwa susunan zat kimia tergantung pada lapisan tanah yang dilalui. Jika melalui tanah kapur, maka air akan menjadi sadah karena mengandung $\mathrm{Ca}\left(\mathrm{HCO}_{2}\right)$ dan $\mathrm{Mg}\left(\mathrm{HCO}_{2}\right)$. Kesadahan ini menyebabkan air sumur menjadi keruh sehingga nyamuk tidak dapat berkembang pada air yang berhubungan langsung dengan tanah. Hal ini sejalan dengan yang disampaikan oleh Budiyanto tahun 2010 bahwa nyamuk dapat berkembangbiak pada air yang tidak berhubungan langsung dengan tanah. $^{13,14}$

Secara keseluruhan ovitrap yang dipasang di luar rumah lebih banyak menghasilkan telur Aedes 
spp daripada ovitrap yang diletakkan di dalam rumah. Fenomena ini mengindikasikan bahwa aktifitas bertelur nyamuk Aedes lebih banyak terjadi di luar rumah.Hal ini berkaitan dengan kelembaban udara dan curah hujan. Penelitian dilakukan selama musim hujan sehingga terjadi peningkatan kelembaban udara dan curah hujan. Kelembaban udara akan mempengaruhi kebiasaan nyamuk untuk meletakkan telurnya. kelembaban udara yang tinggi akan mengurangi penguapan air dalam tubuh nyamuk sehingga menyebabkankan cairan tubuh nyamuk juga meningkat. Nyamuk dapat bertahan hidup dan berkembang biak serta bertelur dengan baik. Selain itu, curah hujan juga mempengaruhi kelembaban udara dan dapat menambah breeding place bagi nyamuk. Pada musim hujan kemungkinan jumlah nyamuk meningkat karena kelembaban udara tinggi serta container di luar rumah dapat menampung air sehingga telur di luar rumah lebih banyak ditemukan. $^{11}$

Hasil penelitian ini sesuai dengan yang dilakukan oleh Sayono pada tahun 2008 yang menemukan bahwa ovitrap yang dipasang di luar rumah menghasilkan jumlah telur lebih banyak daripada ovitrap yang terdapat di dalam rumah. Namun, hasil penelitian ini berbeda dengan hasil penelitian Boewono et al tahun 2006 yang menemukan bahwa ovitrap yang dipasang di dalam rumah menghasilkan jumlah telur yang terperangkap lebih banyak daripada ovitrap yang dipasang di luar rumah. Hal ini terjadi karena lokasi penelitian dan faktor lingkungan yang mempengaruhinya. Penelitian ini dillakukan pada daerah yang padat jumlah penduduk dan jarak antar rumah yang berdekatan serta penelitian terjadi pada musim hujan sehingga breeding place di luar rumah meningkat. Boewono et al tahun 2006 melakukan penelitian pada musim kemarau sehingga masyarakat kesulitan dalam mendapatkan air untuk keperluan sehari-hari. Kondisi ini membuat masyarakat Salatiga jarang membersihkan bak di kamar mandi. hal ini akan meningkatkan breeding place bagi nyamuk Aedes dalam rumah. ${ }^{8,11}$

Sebagian telur ditetaskan menjadi nyamuk dewasa kemudian dilakukan identifikasi sehingga didapatkan jumlah nyamuk Aedes aegypti lebih banyak ditemukan didalam rumah sedangkan nyamuk Aedes albopictus lebih banyak ditemukan di luar rumah. Aedes aegypti suka beristirahat di tempat yang gelap, lembab dan tersembunyi dalam rumah. ${ }^{12}$ Nyamuk Aedes albopictus lebih banyak ditemukan di luar rumah karena Aedes albopictus merupakan nyamuk kebun (forest mosquito) yang memperoleh makanan dengan cara menggigit dan menghisap darah dari berbagai jenis binatang, berkembang biak di dalam lubang pohon, potongan bambu dan buah kelapa yang tebuka.Kondisi ini menyebabkan spesies ini banyak di jumpai di luar rumah. ${ }^{7}$

Perubahan lingkungan seperti pembukaan lahan baru yang dijadikan sebagai komplek perumahan mungkin menyebabkan nyamuk Aedes albopictus kehilangan habitat aslinya dan bertahan hidup di area lain dengan kerapatan vegetasi yang cukup. Komplek perumahan di lingkungan perkotaan menjadi habitat yang baik bagi nyamuk Aedes albopictus yang bermigrasi dari habitat asalnya di hutan, vegetasi rapat pedesaan dan pinggir kota. ${ }^{7}$

Pada Tabel 3 dapat diketahui dari uji rekapitulasi uji statistik krusskal walls $\mathrm{p}=0,000$ yang menandakan bahwa $p<\alpha, \alpha=0,005$, terdapat perbedaan jumlah telur pada masing-masing media ovitrap yang digunakan terhadap jumlah telur Aedes spp yang terperangkap. Rekapitulasi uji Mann Whithney, terdapat signifikansi perbedaan antara jumlah telur yang terperangkap pada air mineral dan jumlah telur yang terperangkap pada air sumur $(p=0,004<0,05)$; perbedaan jumlah telur Aedes spp yang signifikan juga terdapat pada air mineral dan air kolam ( $p=0,004<0,05)$; begitu juga pada air sumur dan kolam yang mempunyai perbedaan yang signifikan $(p=0,006<0,05)$; dan perbedaan jumlah telur yang signifikan juga terdapat pada air kolam dan air jerami $(p=0,004<0,05)$. Jumlah telur Aedes spp antara air mineral dan air jerami tidak terdapat perbedaan yang signifikan. Syarat jika tidak terjadi perbedaan yang signifikan adalah $p<\alpha, \alpha=0,05$.

\section{KESIMPULAN}

Media yang paling efektif dalam penggunaan ovitrap adalah air jerami sedangkan media yang paling kurang efektif adalah air sumur. 


\section{DAFTAR PUSTAKA}

1. Firdaus $A$. Karakteristik penderita demam berdarah di Puskesmas Kabupaten Karimun Propinsi Riau Tahun 1998-2002 (skripsi). Medan: IImu Kesehatan Masyarakat Universitas Sumatera Utara; 2003.

2. Widoyono. Penyakit-penyakit iklim tropis epidemiologi, penularan, pencegahan, dan pemberantasannya. Edisi ke-1. Jakarta: Erlangga; 2005.

3. Suroso $\mathrm{T}$, Umar AL. Epidemiologi dan penanggulangan penyakit demam berdarah dengue (DBD) di Indonesia saat ini. Dalam: Hadinegoro SRH, Satari HI, editor (penyunting). Demam Berdarah Dengue. Jakarta: Penerbit FKUI; 2004.

4. Dinas Kesehatan Sumatera Barat. Profil kesehatan tahun 2012. Padang; 2012.

5. Dinas Kesehatan Kota Padang. Profil kesehatan tahun 2012. Padang; 2012.

6. Astuti D. Upaya pemantauan nyamuk Aedes aegypti dengan pemasangan ovitrap di Desa Gonilan Kartasura Sukoharjo. Jurnal warta. 2008; 11(1):90-8.

7. Suroso T, Hadinegoro SR, Wurijad S, Simanjuntak G, Umar AL, Pitoyono PJ, et al. Pencegahan dan penanggulangan penyakit demam dengue dan demam berdarah dengue. Edisi ke-1. Jakarta: Ditjen PPM \& PL; 2003.

8. Sayono. Pengaruh modifikasi ovitrap terhadap jumlah nyamuk Aedes aegypti yang terperangkap (tesis). Semarang: Program S2 Epidemiologi Universitas Diponegoro; 2008.

9. Data Wilayah Kelurahan Jati. Profil wilayah kelurahan Jati. Padang; 2012.

10. Lelono A. Preferensi betina Aedes aegypti (Dipteral: culicide) pada bermacam media oviposisi potensial di lingkungan. Prosiding Seminar Nasional Entomologi V "Pemberdayaan Keanekaragaman Serangga untuk Peningkatan Kesejahteraan Masyarakat". Bogor: Institut Pertanian Bogor; 2010 Mei 20. hlm.417-9.

11. Boewono DT, Barodji, Suwasono H, Ristiyanto, Widiarti, Widyastuti $U$, et al. Studi komprehensif penanggulangan dan analisis spatial transmisi demam berdarah dengue di wilayah kota Salatiga. Prosiding Seminar Sehari "Strategi Pengendalian Vektor dan Reservoir pada Kedaruratan Bencana Alam di Era Desentralisasi. Salatiga”. Balai Besar Penelitian dan Pengembangan Vektor dan Reservoir Penyakit. 2006. hlm.98 - 115.

12. Pelawi HI. Gambaran indeks jentik nyamuk Aedes aegypti dan kaitannya dengan kejadian demam berdarah dengue di Kelurahan Gung Negeri Kecamatan Kabanjahe Kabupaten Karo Tahun 2006 (skripsi). Medan: Ilmu Kesehatan Masyarakat Universitas Sumatera Utara (USU); 2006.

13. Budiyanto A. Pengaruh perbedaan warna ovitrap terhadap jumlah telur nyamuk Aedes spp yang terperangkap. Jurnal Aspirator. 2010;2(2):99-102.

14. Pandujati A. Daya tetas telur aedes aegypti pada air tercemar (skripsi). Semarang: IImu Kesehatan Masyarakat Universitas Muhammadiyah; 2009. 